\title{
Assessment of integrated index of environmental units of the transport system
}

Gennady I. Shulga*, Alex O. Kolesnichenko, Eugene V. Skrynnikov, Tatiana G. Shulga, and Maxim A. Vasilyev

Platov South-Russian State Polytechnic University (NPI), 346400 Novocherkassk, Russia

\begin{abstract}
Transport-technological complex environmental impact, drivers and participants in the transport process exhaust gases, products of wear of tires, road surface, brake pads and discs and other harmful substances..Proposed air pollution on roads and highways to estimate the complex index of atmospheric pollution transport and technological complex (APITTC).
\end{abstract}

\section{Introduction}

According to the analytical Agency "AUTOSTAT" as of July 1, 2018, the Park of vehicles in Russia amounted to 51.2 million units. There were 42.4 million passenger cars, 8 million 186,5 thousand units of commercial vehicles, including light commercial vehicles -4052 million, 3 thousand, trucks-3 733 million,3 thousand, 400,9 thousand buses and other vehicles.

Medical workers in the exhaust gases of automobile transport more than 200 harmful chemicals, the most dangerous of which are: carbon monoxide $(\mathrm{CO})$, hydrocarbons $(\mathrm{CH})$, nitrogen oxides (NOx), dvuoksid sulfur $\left(\mathrm{SO}_{2}\right)$, carbon (C), oxides of lead, benzo(a)pyrene, formaldehyde, and ozone, which is classified by the world health organization (WHO), the priority hazardous substances. and other substances.

Progress of road transport is accompanied by negative consequences: negative impact on the environment of exhaust gas particulate matter (PM) generated in the exhaust gases and the products of wear of tires, road surface, brake pads and brake discs, which interacts with exhaust gas components [1-4].

In terms of growth of output quantities of road transport, the extension of the construction of the road network to improve the reliability, durability, environmental friendliness of the transport system can provide comprehensive tribological studies of friction units of transport and technological complex: a car tire-road brake pad - brake disc , and also research data generated in the friction units wear products that are on the roadway and suspended in the air. It is important to assess the interaction of these products of wear of components of exhaust gases of motor transport that have an adverse impact on the environment, drivers and participants in the transport process.

The message of World tribology Congress President of the International Council on Tribology Professor P. Jost noted [5]: "The Classic definition of tribology through the

\footnotetext{
*Corresponding author: g.shulga41@mail.ru
} 
interaction of surfaces in relative motion is currently significantly deepened and widened: biotribology, ecotrophology, nanotribology and others...already play a prominent and growing role....Particular importance is given to "Green tribology" - the modern name of ecotrophology suggested by Professor Zhang....The purpose and essence of the studies of green tribology are saving resources and energy, protecting the environment and improving the quality of life...".

According to Professor Zhang [6]: "...the objectives of green tribology...low energy consumption, low emissions, low cost of environmental protection and high quality of life." The principles of "Green tribology" which are also stated in [7].

The goal of "Green tribology" implemented the international project "Green tribology" under the guidance of Professor, Dr. P. Josta Dr. B. Houlihan (UK), Dr. D. N. Garkunov (Russia), Professor Dr. G. Polzer (Germany). In our opinion, the principles of "Green tribology" can be implemented for the friction units of transport-technological complex

For the distribution of cities in terms of air pollution the Ministry of natural resources uses a complex index of pollution of atmosphere (API) [8]. API, calculated on the basis of certain instrumental mean annual concentrations of harmful substances (pollutants). The level of air pollution () is created as a result of receipt of hazardous emissions from all sources in the city and of the atmospheric processes affecting transport and dispersion of these substances from their sources. Any impurity entering the atmosphere, may be contained in any part of the city. Changes only the magnitude of its concentration in the atmosphere.

Pollution levels, which are determined by a different set of impurities separately on one or two positions (stations) on the values of the API, may not reflect the full picture of air pollution in the city and, in particular, on urban roads and highways. For estimation of total atmospheric pollution in General, the city uses all the information about the level of air pollution in urban areas is calculated and a comprehensive API that takes into account $n$ pollutants [9]. However, the proposed integrated ISA does not reflect the contamination of the atmosphere on city roads and highways.

When driving the car the impact on the environment is not only the exhaust gases from the combustion of fuel of road transport, but also products of wear of the tires and the roadway, brake pads and discs. These products wear ome into contact with exhaust gases, forming carcinogenic substances more environmentally dangerous than every product wear separately, which is a source of danger to the health of drivers and the transport process participants.

Suggested eco-friendliness of atmospheric air directly on the roads and highways to estimate the complex index of air pollution from transport-technological complex (APITTC):

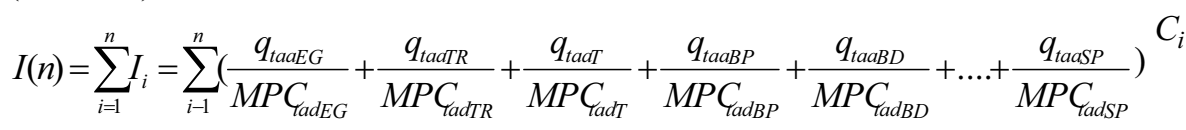

$q_{\text {taa }_{E G}}$ - the annual average concentration of i-th pollutant exhaust gas, $\mathrm{mg} / \mathrm{m}^{3}$;

$M P C_{\operatorname{tad} E G}$ - the average daily maximum permissible concentration of polluting substances in the exhaust gases, $\mathrm{mg} / \mathrm{m}^{3}$;

$q_{\text {taa }_{T R}}$ - the annual average concentration of i-s wear products from the roadway, $\mathrm{mg} / \mathrm{m}^{3}$

$M P C_{\text {tad } T R}$ - the average daily maximum permissible concentration of wear debris from the roadway, $\mathrm{mg} / \mathrm{m}^{3}$

$q_{\text {taa } T}$ - the annual average concentration of i-s wear products from tires, $\mathrm{mg} / \mathrm{m}^{3}$;

$M P C_{\text {tad }_{T}}$ - the average daily maximum permissible concentration of wear products from tires, $\mathrm{mg} / \mathrm{m}^{3}$; 
$q_{t_{a a_{B P}}}$ - the annual average concentration of i-s wear products from brake pads, $\mathrm{mg} / \mathrm{m}^{3}$;

$M P C_{t a d B P}$ - the average daily maximum permissible concentration of wear products from brake pads, $\mathrm{mg} / \mathrm{m}^{3}$;

$q_{t^{\prime a a_{B D}}}$ - the average daily maximum permissible concentration of wear products from brake discs, $\mathrm{mg} / \mathrm{m}^{3}$;

$M P C_{\operatorname{tad} B D}$ - the average daily maximum permissible concentration of wear products from brake discs, $\mathrm{mg} / \mathrm{m}^{3}$;

$q_{\text {taas }}$ - the annual average concentration of i-th pollutant from other sources of pollution, $\mathrm{mg} / \mathrm{m}^{3}$;

$M P C_{\text {tad } S P}$ - the average daily maximum permissible concentration from other sources of pollution , $\mathrm{mg} / \mathrm{m}^{3}$

$C_{i}$ - dimensionless coefficient to allow the degree of harmfulness of the i-th pollutant to the degree of harmfulness of sulfur dioxide.

\section{Materials and methods}

The study of wear debris generated on the roads and highways, was carried out on electron microscope Quanta 200 .On sticky tape applied products of road wear and tear, tyres, brake pads and discs collected in the survey area of the roadway. Put the products of wear in the microscope camera Quanta 200 and determined the dispersion, the chemical composition of the products of wear of the transport system.

The study of exhaust gases and their influence on the wear was carried out on hydraulic brake test stand with engine ZMZ-406, equipped with a gearbox, a device to measure the flow of fuel and air, radiator cooling, devices for measuring temperatures of coolant and exhaust gas control.

Spyway car engine ZMZ-406 is connected through the box changes gear with hydraulic brake by means of a cardan transmission. The engine ZMZ-406 4-cylinder, 16valve with a bore of $92 \mathrm{~mm}$, with a compression ratio of 9.3 , volume- $2286 \mathrm{~cm} 3$, petrol A92, meets the emission standards EURO-3, issued by JSC "Zavolzhsky motor plant".

The interaction of exhaust gases of the engine ZMZ-406.with the products of wear of the investigated units was determined by placing them in a special chamber placed in the exhaust pipe leaving the exhaust gas of the engine. The quantity of exhaust gases $-\mathrm{CH}$ hydrocarbons and $\mathrm{CO}$ carbon monoxide, depending on the engine speed and the load torque was determined according to GOST R 52033-2003 with a gas analyzer AVTOTEST CO$\mathrm{CH}-\mathrm{T}$. the Interaction of wear products from the exhaust gases examined to-date physicochemical methods.

\section{Results and discussion}

The products of wear of friction units of transport-technological complex is shown in Fig.1, consist of products of road wear and tear, tyres, metal products of wear of the brake pads, discs and other substances with different dispersion 


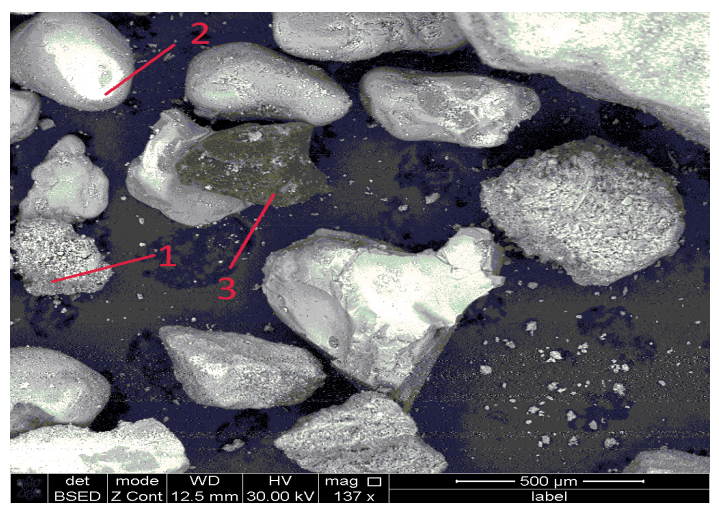

Fig.1. The Products of wear of the transport-technological complex: 1-metallic brake pads and discs, 2 -the products of wear of the roadway, 3-products of tire wear.

The emissions of different amounts of exhaust gas (hydrocarbons $\mathrm{CH}$ and carbon monoxide $\mathrm{CO}$ ) in depending on the load torque $\mathrm{Mn}$ at various frequencies of rotation of the crankshaft 1000,1500 $\mathrm{min}^{-1}$ (Fig.2,3), can form various toxic substances when interacting with the products of wear of friction units.

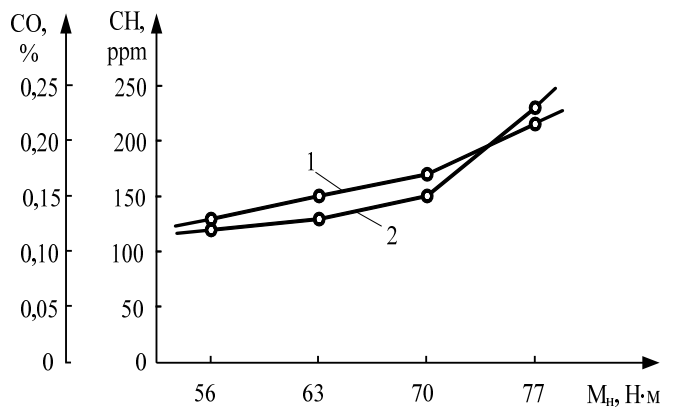

Fig.2. Dependence of the amount of exhaust gas: $\mathrm{CH}$ hydrocarbons and carbon oxide $\mathrm{CO}$ from the load torque $\mathrm{Mn}$ at engine speed 1000 min-1 : $1-\mathrm{CH}$ hydrocarbons, ppm; $2-\mathrm{CO}$ carbon monoxide, $\%$.

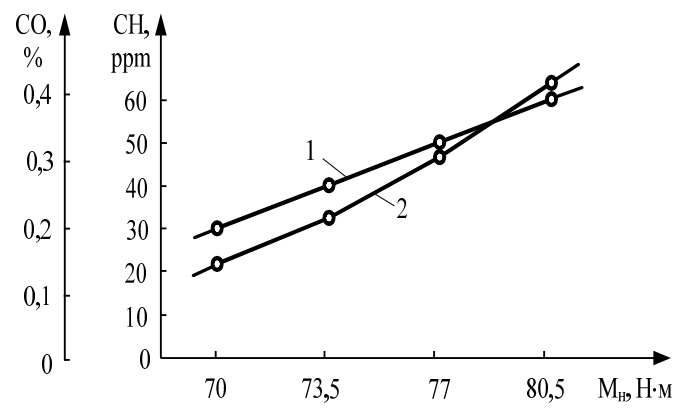

Fig.3. Dependence of the amount of exhaust gas: $\mathrm{CH}$ hydrocarbons and carbon oxide $\mathrm{CO}$ from the load torque $\mathrm{Mn}$ when the engine speed is 1500 min-1: $1-\mathrm{CH}$ hydrocarbons, ppm; $2-\mathrm{CO}$ carbon monoxide, $\%$.

The integrated APITTC will allow assessment of air pollution on the roads and highways transport-technological complex: exhaust gases, wear particles of the roadway, tires, brake pads, discs, and other pollution sources to take into account their integrated 
impact on the environment, drivers, participants in the transport process to develop measures to reduce the negative impact of these substances.

\section{References}

1. V. K. Azarov, V. F. Koutenev, A. M. Saykin, Motor industry, 10, 5 (2013)

2. G. I. Shulga, T. G. Shulga, I. N. Shcherbakov, E. V. Skrynnikov, Proceedings of the forum, NOUN-"Legion", 196-202 (2015)

3. G. I. Shulga, The results of studies in 2016: proceedings of the national conference of teaching staff and researchers, 159 (2016)

4. G. I Shulga, Proceedings of the national conference of teaching staff and researchers, 199 (2017)

5. P. Jost, 5th World Tribology Congress (WTC-2013), Torino (2013)

6. S.-w. Zhang, Friction, 1 (2), 186 (2013)

7. V. Nosonovsky, B. Bhushan, Green Tribology: Biomimetics. Energy Conservation and Sustainability, Springer, Berlin (2012)

8. E. Yu. Bezuglaya, E.K., Zavadskaya. T. P Ivleva et al 52.04.667 RD-2005 Documents on the status of air pollution in cities to inform state bodies, public and population. General requirements for the design, construction, presentation and content. (Meteoagentstvo of ROSHYDROMET, Moscow, 2006).

9. A. D Ziv, V. I. Lichtman, N. D. Sorokin etc. Ecology of production, 10, 44 (2017) 